\title{
Cutaneous melanoma dissemination is dependent on the malignant cell properties and factors of intercellular crosstalk in the cancer microenvironment (Review)
}

\author{
ONDŘEJ KODET ${ }^{1-3}$, JAN KUČERA ${ }^{1,2}$, KAROLÍNA STRNADOVÁ ${ }^{1,3}$, BARBORA DVOŘÁNKOVÁ ${ }^{1,3}$, \\ JIŘÍ ŠTORK ${ }^{2}$, LUKÁŠ LACINA ${ }^{1-3}$ and KAREL SMETANA Jr ${ }^{1,3}$ \\ ${ }^{1}$ Institute of Anatomy, First Faculty of Medicine, Charles University, 12800 Prague 2; \\ ${ }^{2}$ Department of Dermatovenereology, First Faculty of Medicine, Charles University and General University Hospital, \\ 12000 Prague; ${ }^{3}$ Biotechnology and Biomedicine Center of the Academy of Sciences and Charles University \\ in Vestec (BIOCEV), First Faculty of Medicine, Charles University, 25250 Vestec, Czech Republic
}

Received December 29, 2019; Accepted June 15, 2020

DOI: 10.3892/ijo.2020.5090

\begin{abstract}
The incidence of cutaneous malignant melanoma has been steadily increasing worldwide for several decades. This phenomenon seems to follow the trend observed in many types of malignancies caused by multiple significant factors, including ageing. Despite the progress in cutaneous malignant melanoma therapeutic options, the curability of advanced disease after metastasis represents a serious challenge for further research. In this review, we summarise data on the microenvironment of cutaneous malignant melanoma with emphasis on intercellular signalling during the disease progression. Malignant melanocytes with features of neural crest stem cells interact with non-malignant populations within this microenvironment. We focus on representative bioactive factors regulating this intercellular crosstalk. We describe the possible key factors and signalling cascades responsible for the high complexity of the melanoma microenvironment and its premetastatic niches. Furthermore, we present the concept of melanoma early becoming a systemic disease. This systemic effect is presented as a background for the new horizons in the therapy of cutaneous melanoma.
\end{abstract}

Correspondence to: Professor Karel Smetana Jr or Dr Lukáš Lacina, Institute of Anatomy, First Faculty of Medicine, Charles University, U Nemocnice 3, 12800 Prague 2, Czech Republic

E-mail: karel.smetana@lf1.cuni.cz

E-mail: lukas.lacina@lf1.cuni.cz

Abbreviations: CAFs, cancer-associated fibroblasts; CMM, cutaneous malignant melanoma; EMT, epithelial to mesenchymal transition; NC, neural crest; SCs, stem cells; SMA, smooth muscle actin

Key words: melanoma, cancer microenvironment, cancer-associated fibroblast, cytokine, chemokine, growth factor

\section{Contents}

1. Introduction

2. Cutaneous malignant melanoma (CMM) disseminates extensively in the organism of the patient

3. The microenvironment of CMM participates in the control of its invasive potential

4. Differences in serum proteins between CMM patients and healthy individuals

5. Intravasation and extravasation of CMM cells and their inhibition via migrastatics

6. Cancer-associated wasting and cachexia as a terminal complication of CMM; clinically relevant complications are also associated with factors of intercellular crosstalk

7. Conclusion

\section{Introduction}

Similarly toother malignant diseases, the incidence of cutaneous malignant melanoma (CMM) is increasing worldwide (1). This increased incidence seems to be influenced by many factors, including ageing of the population, behavioural habits, and climatic and environmental changes. Formation of CMM is associated with the main genetic drivers such as BRAF, NF1 and NRAS mutations, also usually associated with chronic skin sun damage (2). Aberrant activation of the RAS/BRAF/MEK/ERK signalling pathway causes uncontrolled proliferation of malignant cells in the majority of CMM (3). Melanoma causes most of the skin cancer-related deaths. The patient overall survival at five years depends on the thickness of the primary melanoma. CMM is also known for its remarkable ability to metastasise. Despite the new therapeutic options, the curability of advanced-stage melanoma is still limited. These recent therapeutic approaches modulate the immune response of the organism (e.g., via application of anti-CTLA-4 and anti-PD-1 antibodies) or target proliferation in specifically mutated melanomas (e.g., by application of BRAF or MEK inhibitors). In order to establish novel targeted melanoma therapies, it is 
of fundamental importance to understand the mechanisms activated in the permissive tumour microenvironment. In particular, interactions between melanoma cells and the tissue microenvironment play key roles in the disease progression. This article summarises data on the multifaceted roles of CMM microenvironment in tumour spreading. This concept may be extended to the intravasation of bioactive molecules participating in the melanoma cell crosstalk with non-malignant cells forming the CMM microenvironment. These molecules also participate in premetastatic niche formation. Finally, their role in patient wasting is also widely discussed. The concept of CMM microenvironment as a complex system suitable for therapeutic targeting is introduced in this article.

\section{Cutaneous malignant melanoma (CMM) disseminates extensively in the organism of the patient}

The critical feature associated with melanoma is its enormous capability to spread and form lymph node or distant visceral metastases (Fig. 1). Almost any tissue in the patient's body can host metastatic cells, and even a small and thin primary tumour can metastasise to the entire body, leading to the death of the patient (1). Metastatic spread is a complex multistep process, as was noted almost 200 years ago by surgeon Stephen Paget, who coined the 'seed and soil' hypothesis (4). Surprisingly, cutaneous melanoma can spread to different organs without any particular predilection, and thus differs from, e.g., uveal melanoma of similar histogenesis. However, the first predictive site of metastatic disease is a lymph node. The presence of tumour cells in this lymph node is generally investigated in melanoma patients with tumours thicker than $1 \mathrm{~mm}$. This procedure is routinely called sentinel lymph node biopsy. The presence of melanoma cells in the lymph node is a powerful predictor of melanoma recurrence, but not of survival, in the melanoma patients (5). VEGF-C, which is involved in lymphangiogenesis and promotes increased lymphatic vessel density, can also play a role in lymph node metastasis (6).

CMM metastasis to the lungs and brain and other visceral organs. In the case of visceral melanoma metastasis, the most predictive localisations are the lungs and pleura (7). Lung metastases are also the most frequent metastases in mouse models of metastatic melanoma (8). In these mouse models using the B16 model of melanoma, chloride channel accessory 2 (CLCA2), an extracellular protein expressed predominantly in the lung, was identified as a factor mediating interactions with $\alpha 6 \beta 4$-integrin, which is expressed by tumour cells (9). Brain metastases are associated with poor prognosis. Historically, melanoma patients with brain metastases have had dismal outcomes and very limited treatment options. Systemic treatment with BRAF inhibitors and immunotherapy offers therapeutic responses in up to $55-58 \%$ of patients (10). The actual mechanism of brain metastases is not clear, but mouse models point to some factors that play a role in this process. The original model suggested a role of transferrin receptors and their interaction with their ligand, transferrin, mediating metastases of melanoma cells to the brain. Another study highlighted the importance of neurotrophins and neurotrophin receptors in the process of brain-specific melanoma metastases (11).
Other common sites for melanoma metastases are the liver (up to $20 \%$ of patients), bones (11-17\%), or skin and subcutaneous tissue (12).

CMM metastasis to the skin. Skin metastasis represents haematogenous dissemination of melanoma cells. Specific interactions between chemokines $\mathrm{C}-\mathrm{C}$ motif chemokine receptor 10 (CCR10) and $\mathrm{C}-\mathrm{C}$ motif chemokine ligand 27 (CCL27) have been determined as crucial factors in melanoma metastasis to the skin (13). CCL27 is a chemokine expressed in the epidermis by normal keratinocytes. In addition, high expression in supratumoral epidermis is associated with more prolonged melanoma-specific survival (14). Presumably, CCL27 interacts with the chemokine receptor CCR10, which is expressed in melanoma cells. Experiments with blocking antibodies to CCL27 showed inhibition of development of skin metastasis in a mouse model (15).

CMM metastasis and somatic mutations. Despite that, no specific biomarker with predictive potential to determine the metastatic site exists to date. In melanoma, there is also an observed lack of association between the site of visceral or lymph node metastasis and either the clinicopathological variant or location of the primary tumour (16). The dependence on the presence of somatic mutations has been reported. One study suggested that BRAF mutation is associated with lymph node metastasis as the first metastasis and sentinel lymph node positivity. BRAF and NRAS mutations were associated with different metastatic patterns, with metastases more frequently affecting the central nervous system and the liver. NRAS-mutated tumours formed lung metastases (17). This highlights an earlier-unexpected internal heterogeneity of the group of tumours nowadays collectively called melanoma. Although intense visceral organ-specific surveillance may be initiated in patients with tumours harbouring these somatic mutations, this does not necessarily lead to a decrease in mortality. It is not easy to understand this metastatic potency of CMM, which represents the main, frequently fatal, complication in the treatment of patients. The complexity of these mechanisms is also shown by the concept of pre-malignant melanocyte dissemination, suggesting that benign melanocytes may exist at disseminated sites in the body and may be capable of undergoing malignant progression. It is not uncommon to find benign melanocytic nevi in the lymph node during sentinel lymph node biopsy or in non-melanoma patients (up to $7 \%$ of patients) (18). These findings support the hypothesis mentioned above. It is also critically important to identify the mechanisms driving the metastatic behaviour.

CMM cells are similar to neural crest-originated stem cells. CMM cells arise after malignant transformation from pigment-producing cells called melanocytes. Melanocytes originate from the embryonic neuroectoderm structure called the neural crest (NC). NC cells are multipotent stem cells derived from the neuroectoderm that delaminate from the neural tube in early vertebrate development (in the 4th week) and migrate throughout the developing embryo. Consequently, $\mathrm{NC}$ cells differentiate into various cell lineages, including melanocytes (19). 

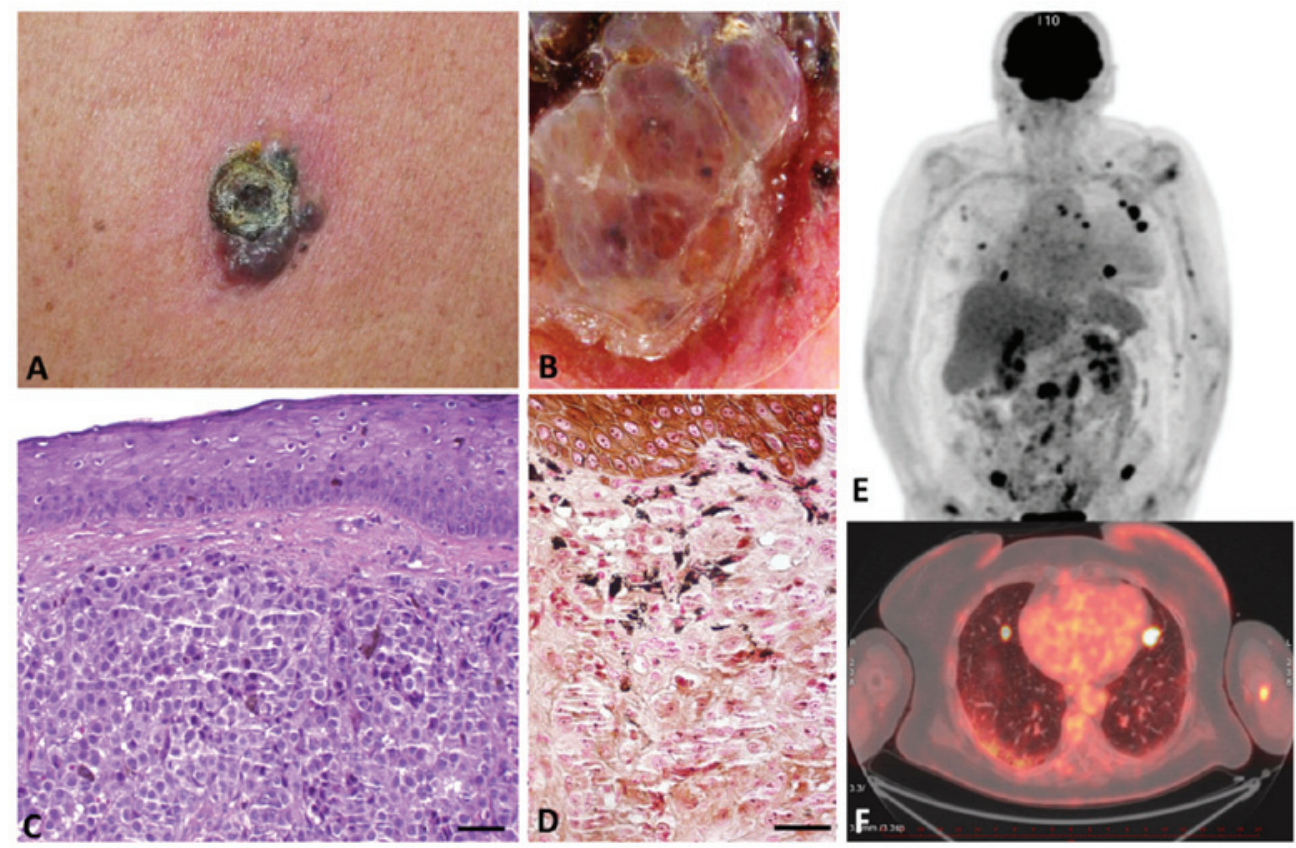

Figure 1. This figure presents the extensive capability of melanoma to form lymphatic/distant metastases in all tissues in the patient's body documented at a single patient level. (A) Primary cutaneous melanoma (Breslow thickness $6 \mathrm{~mm}$ ) with clinical apparent ulceration in a 69-year-old female, and (B) dermoscopy of this primary cutaneous melanoma with atypical black dots, dotted vessels and erythema in regression areas. (C) The same primary tumour stained with H\&E; magnification, x200. (D) After staining with Fontana-Masson (melanin), dark black granules of melanin in melanoma are visualised; magnification, x400 (E) PET-CT scan shows generalisation of the tumour to the lung, bones, lymph nodes, and soft tissue. (F) Horizontal section of PET-CT scan demonstrates metastasis in the lung and left humerus. The images were kindly provided by the Department of Dermatovenereology, First Faculty of Medicine, Charles University with explicit informed consent.

NC cells are unique because of their remarkably broad differentiation potential (Table I) (20-22). Once they have reached the final tissue niche in the skin, NC cells differentiate to melanocytes by a cascade of events controlled by transcription factors such as microphthalmia-associated transcription factor (MITF) and sex-determining region Y-box 10 (Sox 10). This process occurs during the prenatal period of human development $(23,24)$. The signalling molecules and transcription factors that are required for NC cell specification, migration and differentiation form a highly orchestrated gene regulatory network. Every individual signalling molecule has either individual or combinatorial roles in transcriptional regulation (25). The precise understanding of this mechanism seems to be critically important because similar pathways are activated in malignancy, and they could control the biological properties of malignant CMM cells (26). The signalling pathways regulating epithelial to mesenchymal transition (EMT) can be triggered by transcription factors that are active in both $\mathrm{NC}$ development and cancer progression (27).

Interestingly, both melanoblasts and $\mathrm{NC}$ cells also reside in the bulge region of the hair follicle in the outer root sheath. In this highly specialised niche, $\mathrm{NC}$ cells retain their multipotency during adult life. NC cells can be isolated and expanded in vitro with the remarkable features of highly multipotent stem cells (SCs). It is possible to differentiate NC cells to various specialised cell types such as melanocytes, adipocytes, osteoblasts, chondroblasts, smooth muscle cells, neurons, and Schwann cells (28). The NC cell phenotype is defined by expression of multiple markers, and $\mathrm{NC}$ cell identification cannot be based on a single molecule. Of note, there is a significant overlap with the marker profile of CMM [Table II based on (29-37)].
This highlights the low differentiation frequently observed in melanoma, where many cells typically have properties of stem cells (37). These cancer-initiating cells of CMM have an indispensable role in CMM resistance to therapy, progression and generalisation (38).

The life-long postnatal presence of NC cells in hair follicles raises important questions regarding the maintenance of their multipotency and regulation of their normal behaviour within this niche. There is strong evidence that the microenvironment is a critical condition of this steady-state. The signalling cues within the proper microenvironment, via both extrinsic and intrinsic factors, orchestrate the interplay necessary for healthy tissue dynamics. The importance of the normal tissue microenvironment was highlighted in several studies using transplantation of malignant cells to animal embryos. In experiments performed in the early chicken embryo, labelled CMM cells were injected into the region of the neural tube. It was demonstrated that melanoma cells migrate to the same regions as the autologous embryonic NC cells (39). Similar experiments performed later in zebrafish embryos supported these findings. Both the embryonic NC cells and the cells of CMM in zebrafish express specific protein crestin, which is absent in normal melanocytes (40).

Taking into account the low differentiation status of NC cells and their natural migratory activity, the similarity of CMM and NC cells can also explain the highly metastatic behaviour observed in melanoma in the clinic.

Circulating CMM cells in disease dissemination. Similarly to other types of malignant tumours, cells of CMM can also be detected in the circulation. These circulating melanoma 
Table I. Examples of cells originated from neural crest cells.

\begin{tabular}{ll}
\hline Cell type & \multicolumn{1}{c}{ Specification } \\
\hline Peripheral neurons & $\begin{array}{l}\text { Sensory, sympathetic + } \\
\text { parasympathetic ganglia }\end{array}$ \\
Glial cells & $\begin{array}{l}\text { Schwann cells } \\
\text { Mechanoreceptor function }\end{array}$ \\
Merkel cells & Production of calcitonin \\
Parafollicular cells & Chromaffin cells \\
Adrenal medullar cells & Facial skeleton \\
Osteoblasts/odontoblasts & Facial skeleton \\
Chondroblasts & Striated/smooth-facial \\
Myoblasts & region \\
& Multipotent stem cell \\
Dental pulp cells & potential \\
Fibroblast/mesenchymal cells & Facial region \\
Cornea & Stromal cells \\
Melanocytes & All parts of the body \\
\hline
\end{tabular}

cells harbour the functional properties of cells of the primary tumour, including their SC-like properties $(41,42)$. These cells leave the primary tumour and penetrate the vessels and use them as a highway for dissemination through the patient's body to target the organ/tissue where they form metastases. Using an identical vascular path, the normal adult tissue SCs can migrate in order to facilitate body repair processes during wound healing $(43,44)$. From this point of view and based on histological/molecular similarity, cancer again resembles wound healing. With a certain hyperbole, cancer can be seen as a distorted cascade of wound repair events (45). These data can also predict the great invasive metastatic potential of CMM.

\section{The microenvironment of CMM participates in the control of its invasive potential}

Melanoma is a complex ecosystem. Malignant cells define the type of tumour. However, there are other non-cancerous populations forming the tumour stroma. It is the interaction of both components of this microenvironment that finally defines the biological behaviour of the tumour. It is truly applicable to solid tumours in general, and CMM is no exception (46-48). Concerning CMM, the cancer microenvironment is formed by cancer-associated fibroblasts (CAFs) and several types of leukocytes, as comprehensively reviewed by Lacina et al (49) (Fig. 2A).

The origin of CAFs is not fully understood. Local normal dermal fibroblasts, attracted mesenchymal SCs and pericytes are frequently mentioned as source cell populations from which CAFs are recruited (50). However, the transition of cancer cells to CAFs cannot be entirely excluded, although its likeliness is not very high. This fact is difficult to prove in the experimental model (51).

Treg lymphocytes, tumour-associated macrophages and myeloid-derived immunosuppressive cells stimulating the CMM progression, as well as NK cells, macrophages and
Table II. Comparison of markers of hair follicle NC SCs and CMM cells.

\begin{tabular}{lcc}
\hline Factor & NC SCs & CMM cells \\
\hline BMP4 $^{\mathrm{a}}$ & + & + \\
SNAIL $^{\mathrm{a}}$ & + & + \\
SLUG $^{\mathrm{a}}$ & + & + \\
SOX9 $^{\mathrm{a}}$ & + & + \\
TWIST $^{\mathrm{a}}$ & + & + \\
MITF $^{\mathrm{b}}$ & + & + \\
Desmin $^{\mathrm{c}}$ & + & $+/-$ \\
Calponin $^{\mathrm{c}}$ & + & $+/-$ \\
$\beta$-III tubulin & + & + \\
\hline
\end{tabular}

${ }^{\mathrm{a}} \mathrm{NC}$ marker, ${ }^{\mathrm{b}}$ melanocyte progenitor marker, ${ }^{\mathrm{c}} \mathrm{smooth}$ muscle differentiation marker, ${ }^{\mathrm{d}}$ neuronal marker. NC, neural crest; SCs, stem cells; CMM, cutaneous malignant melanoma; BMP3, bone morphogenetic protein 3; SOX9, SRY-box transcription factor 9; MITF, microphthalmia-associated transcription factor. Based on Person et al (29), Stasiak et al (30), Yang et al (31), Lee et al (32), Tudrej et al (33), Iwakami et al (34), Goding and Arnheiter (35), Campbell et al (36), Krejčí and Grim (37).

CD8-positive T lymphocytes, are attracted to the CMM site. Interestingly, CAFs stimulate the activity of immune cells supporting melanoma cells and inhibit the cancer-suppressing cells $(52,53)$.

Unlike in other epidermal tumours, keratinocytes are also an important component of the CMM microenvironment. Melanoma cells can stimulate surrounding keratinocytes (54). On the other hand, keratinocytes control growth and differentiation of melanocytes and potentiate the invasiveness of melanoma cells during early progression as observed in a reconstructed skin model (55).

Role of intercellular contact. Cell-cell adhesion molecules (cadherins) and cell-extracellular matrix adhesion proteins (integrins) play a critical role in the regulation of cancer invasion and metastasis. Many members of the cadherin superfamily play an important role in cancer biology. However, the most significant explanation is seen in the E-/N-cadherin switch, and its role in epithelial to mesenchymal transition (EMT), in cancer progression. $\mathrm{N}$-cadherin expression in CMM cells helps cancer cells to interact with fibroblasts and extracellular matrix and stimulates the invasive potential of melanoma cells and their proliferation, but also activation of PI3/AKT, mTOR, and ERK kinase. Inhibition of $\mathrm{N}$-cadherin represents an interesting possibility, with potential clinical use (56).

Intercellular contacts of normal melanocytes, or malignant melanoma cells, respectively, and their non-cancerous neighbours within the tissue environment influence their properties mutually (62). Keratinocytes reduce expression of N-cadherin not only via cell-cell contacts, but also via cell-derived extracellular matrix and conditioned medium with calcium regulators (57). These findings support the importance of the balance in communications between melanoma cells and non-cancerous cells in the melanoma microenvironment. 


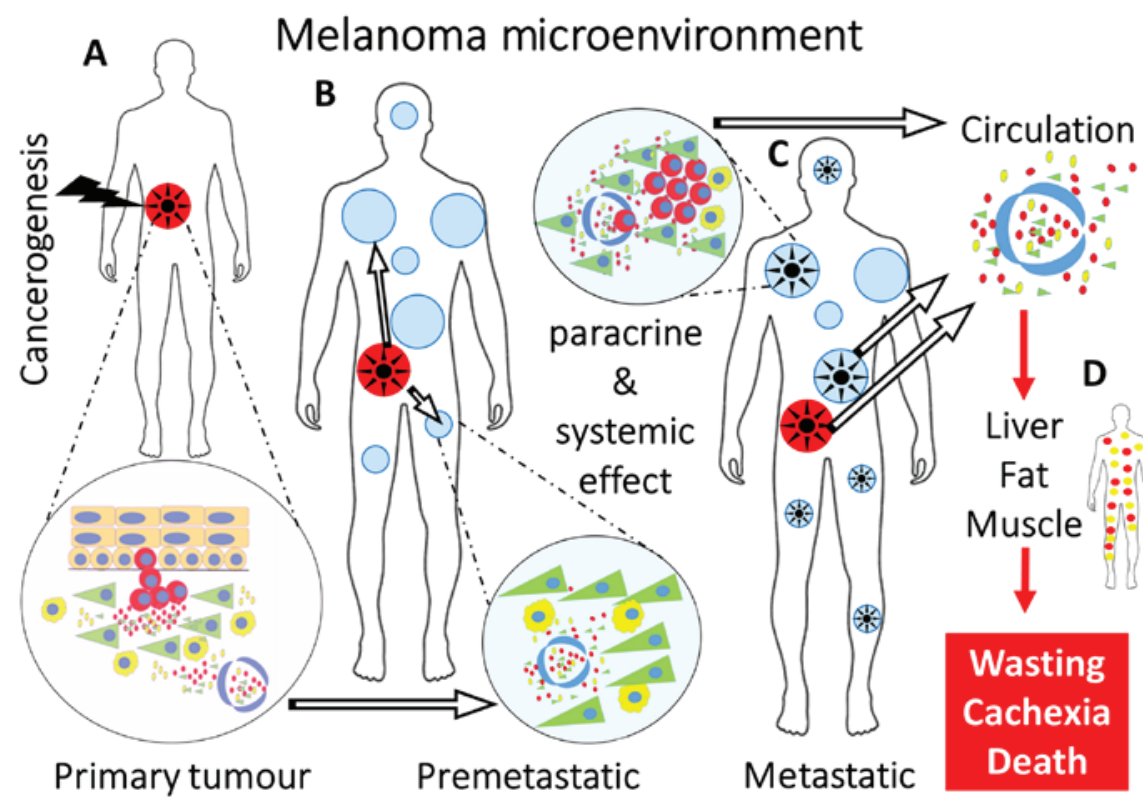

Figure 2. The figure demonstrates the paracrine and systemic effect of CMM during progression. (A) Once initiated, the tumour growths and via paracrine signalling influences surrounding non-cancerous tissues (detail in the pink-filled circle). This paracrine interaction strengthens the malignant potential of CMM. However, signalling molecules diffuse and also leak to the circulation via capillaries. (B) Exposed to the released cytokines, chemokines and growth factors, the normal distant tissues become activated and form premetastatic niches (detail in the blue-filled circle). This is an early systemic effect of the primary tumour. (C) In some of these niches, the metastasising malignant cells will harbour and initiate a metastatic tumour (detail in the blue-filled circle). The concentration of circulating bioactive molecules is further enhanced by their production in metastases. This represents a later systemic effect typical of generalised malignancies. (D) Circulating bioactive molecules induce physical and functional organ changes. This consequently results in wasting, cachexia and death. CMM, cutaneous malignant melanoma.

Integrins $\beta 1$ and $\beta 3$, as adhesion cell-extracellular matrix proteins, are differentially expressed during the transformation of melanoma radial growth to the vertical invasion $(58,59)$. The differentiation status of melanoma cells and the ability to invade the surrounding tissue also highlights this impact. For example, the expression of connexin-43 in CMM cells indicates the ability of CMM cells to metastasise $(52,60,61)$. Expression of desmoglein-2, which participates in the contacts with keratinocytes, has an inhibitory effect on CMM cell migration.

On the other hand, the expression of desmoglein-2 promotes the vasculogenic mimicry of CMM cells, which is associated with a poor outcome of patients $(62,63)$. Furthermore, in melanoma cells that do not express $\beta 3$ integrins, $\beta 1$ integrins instead play a role in promoting their transendothelial migration by binding to vascular cell adhesion molecule 1 (VCAM-1) (64). Integrins also play an important role in connecting the extracellular matrix with the melanocyte and melanoma cell cytoskeleton. Cytoskeletal rearrangements, such as the increase of the overall contractility, impact cell mechanical properties and cell deformability. These changes may then potentiate prometastatic phenotypes of melanoma cells. Expression of $\alpha v \beta 3$ integrin increases elasticity in human melanoma cells in adherent and non-adherent conditions (65). Intercellular contacts and molecules play an important role in the mechanisms of targeted therapy. Targeting of the CMM cell surface receptor Notch-dependent pathway improves the activity of Erk inhibitors in BRAF-V600E mutated tumours. Further, it can be combined with inhibition of ERBB3 to suppress melanoma cell growth (63). On the other hand, Notch expression in CAFs reduces the growth and migration potential of melanoma cells (66).
Role of paracrine signalling in communication across the CMM microenvironment. The paracrine mode of signalling between cancerous and non-cancerous cells in CMM has been extensively studied (Fig. 2B and C). For example, CAFs, keratinocytes and infiltrating immune cells produce a variety of growth factors/cytokines/chemokines that significantly influence the biological properties of malignant CMM cells $(67,68)$ (Table III). Interestingly, many of these factors are also associated with skin ageing. Collectively, these bioactive molecules are called the senescence-associated secretome (69). As expected, chemokines attract inflammatory cells to the tumour site. However, they also have multiple other functions (70). CMM cells express receptors for CXCL1 and interleukin (IL)8, and these factors enhance their invasiveness $(71,72)$. Antagonists of CXCR1/2 receptors have a well-documented inhibitory effect on migration of CMM cells (73). The IL8 chemokine also stimulates vascularisation of CMM $(74,75)$, and in general, its high expression indicates poor prognosis of CMM patients (76).

Expression of chemokine CXCL16 seems to participate in the malignant transformation of a melanocytic nevus to CMM (77). Activation of CXCR6 recognising this chemokine induces SC-like properties in CMM cells and initiates their migration (78).

IL1 $\beta$ is predominantly produced by macrophages. It participates in the progression of CMM in collaboration with IL8 and caspase recruitment domain family member 8 (CARD8) (79).

IL6 is a crucial factor initiating the immune response. IL6 has a multifaceted role in cancer progression (80). While the initial stage of CMM growth can be inhibited by IL6 (81), the more advanced stages are associated with production of 
Table III. Examples of factors produced by CAFs, Kerat and melanoma cells in CMM.

\begin{tabular}{|c|c|c|c|c|}
\hline Symbol & Gene name & CAFs & Kerat & CMM cells \\
\hline IL8 & Interleukin 8 & + & + & + \\
\hline CXCL1 & $\begin{array}{l}\text { Chemokine (C-X-C motif) ligand } 1 \\
\text { (melanoma growth stimulating activity } \alpha \text { ) }\end{array}$ & + & - & - \\
\hline CXCL16 & Chemokine (C-X-C motif) ligand 16 & + & - & + \\
\hline IL1B & Interleukin $1 \beta$ & + & - & - \\
\hline IL6 & Interleukin 6 & + & + & + \\
\hline$I L 17 D$ & Interleukin $17 \mathrm{D}$ & + & - & + \\
\hline$A C A N$ & Aggrecan & + & + & + \\
\hline$H B E G F$ & Heparin-binding EGF-like growth factor & + & + & - \\
\hline$B D N F$ & Brain-derived neurotrophic factor & - & - & + \\
\hline$T G F B 2$ & Transforming growth factor, $\beta 2$ & - & - & + \\
\hline IGFBP7 & Insulin-like growth factor binding protein-7 & + & + & - \\
\hline GAP43 & Growth associated protein 43 & + & + & - \\
\hline BMP2 & Bone morphogenetic protein 2 & + & - & + \\
\hline BMP6 & Bone morphogenetic protein 6 & + & - & - \\
\hline$V E G F A$ & Vascular endothelial factor A & + & + & + \\
\hline$V E G F C$ & Vascular endothelial factor $\mathrm{C}$ & + & + & + \\
\hline$C T G F$ & Connective tissue growth factor & + & - & + \\
\hline PDGFRL & Platelet-derived growth factor receptor-like & + & - & + \\
\hline LEPRE1 & Leucine proline-enriched proteoglycan (Leprecan) & + & - & - \\
\hline LEPREL1 & Leprecan-like 1 & + & - & + \\
\hline KAZALD1 & Kazal-type serine peptidase inhibitor domain 1 & + & - & - \\
\hline
\end{tabular}

CAFs, cancer-associated fibroblasts; CMM, cutaneous malignant melanoma; Kerat, keratinocytes. Based on Kodet et al (54), Jobe et al (67).

this interleukin $(82,83)$. IL6, frequently in cooperation with IL8, exhibits an additive effect on WNT5A in the stimulation of CMM cell invasiveness (67,84). IL6 induces Twist and $\mathrm{N}$-cadherin expression in CMM angiogenesis in a mechanism dependent on the p50 subunit of nuclear factor $\kappa \mathrm{B}(85)$.

In general, IL17D (IL27) has an anti-tumoral effect in CMM (86), where it participates in generating tumour-specific cytotoxic T cells (87). The effect of IL17D on CMM cells seems to be TRAIL-dependent (88). On the other hand, it is also known as a potent inducer of the production of IL6 and IL8 in endothelial cells. It is highly expressed in the initial stages of CMM (89), stimulating the CMM growth and tumour vascularisation.

Glycoprotein aggrecan is produced by cells of the CMM, CAFs and keratinocytes. It is usually secreted during the process of chondroblast differentiation, and it has an inhibitory effect on CMM progression (90). A similar anti-CMM effect is produced by insulin-like growth factor-binding protein 7 (IGFBP-7), namely in BRAF-mutated V600E-positive dysplastic nevi (91). On the other hand, heparin-binding EGF-like growth factor has a stimulatory impact on CMM growth (92). The same result was described in the case of another growth factor, neurotrophin $(93,94)$. miRNA-328 controls production of TGF- $\beta 2$, and attenuation of its expression has a strong inhibitory effect on CMM cell proliferation (95). VEGFA and VEGFC are generally responsible for the activation of CMM neovascularisation by blood/lymphatic vessels that support the CMM growth and progression. Connective tissue growth factor has a synergistic effect on VEGFA and stimulates the tumour site neovascularisation (96).

As mentioned earlier, CAFs do not support tumour growth and metastases exclusively. CAFs are also implicated in the acquisition of resistance to the targeted therapy in BRAF-mutated melanomas. Under the influence of BRAF inhibitors, CAFs secrete factors that contribute to CMM cell survival and melanoma resistance. CAFs release factors such as hepatocyte growth factor (HGF) and neuregulin 1 (NRG1), which can trigger alternative cascades in MAP kinase signalling $(97,98)$.

The short overview in Table III demonstrates the complexity of signalling between CMM cells and non-cancerous cells, where intercellular contacts, cytokines, chemokines, and growth factors with both the stimulatory and inhibitory effect influence the tumour growth and generalisation.

Concluding this paragraph, paracrine signalling represents a critical aspect in the control of biological properties of CMM. In addition to the crosstalk between melanoma cells, this process includes an exchange of information between CMM cells and non-malignant cells of the microenvironment.

Role of exosomes. In addition to paracrine signalling via soluble products, exosomes represent another tool of CMM cell communication with non-cancerous partners within the microenvironment. All affected cell populations of the cancer microenvironment produce these bodies. Exosomes thus influence CMM cell biological properties (99). 
Exosomes stimulate CMM cell metastasis via support of the epithelial-mesenchymal transition. Exosomes influence vascularisation of the lymph node in order to prepare the vascular bed for the metastasising $(100,101)$. Exosomes significantly participate in the regulation of local invasiveness and also in the entrance of melanoma cells to the target organs (102). This effect is frequently associated with the presence of miRNAs in CMM-derived exosomes. It was confirmed both in vitro and in vivo in clinical material (103). Exosomes exert a robust immunosuppressive effect on the cancer microenvironment, where they inhibit IL2-dependent proliferation of CD8-positive T lymphocytes (104). Moreover, CMM exosomal miRNA-125b-5p induces a tumour-promoting phenotype in macrophages (105). These changes can induce a mixed M1, and M2 tumour-promoting macrophage activation included production of CCL22, IL-12B, IL-1 $\beta$, IL-6, i-NOS, and TNF- $\alpha$ (106). These data highlight exosomes as a critically important component of the CMM microenvironment significantly participating in its biological properties, with the ability to stimulate the immune response of the melanoma microenvironment.

\section{Differences in serum proteins between CMM patients and healthy individuals}

Serological biomarkers represent a diverse group of biomolecules with importance in diagnosis, staging, and monitoring the therapeutic response. Serum lactate dehydrogenase (LDH) is the only serum biomarker that has been accepted as a prognostic biomarker for routine clinical use in melanoma patients with a predictive therapeutic outcome and has been implemented in the American Joint Committee on Cancer (8th edition) staging system (107). Routinely used S100B (S100 calcium binding protein B) protein is highly specific for melanoma patients. Its increased levels can be detected in patients with advanced melanoma during melanoma prognosis (108). Another serological protein is MIA (melanoma inhibitory activity), which interacts with extracellular matrix proteins. Its expression can also be detected in normal tissue such as cartilage. In pathological processes, its overexpression is observed in breast cancer or colorectal cancer, in addition to melanoma (109).

Introduction of a new treatment strategy for advanced melanoma leads to the search for new biomarkers to improve both prognostic and predictive outcome. Likely, the high intensity of molecular exchange between cancer cells and other members of the microenvironment via cytokines, chemokines and growth factors can lead to leakage out from the tumour microenvironment, and mediators can be consequently detected in systemic circulations in the serum $(110,111)$ (Fig. 2A-D). Therapy by monoclonal antibodies targeting immune checkpoint inhibitors is one of the most potent treatments of CMM patients. Measurement of current concentrations and dynamics of these mediators in the serum can have the potential of liquid biopsy. Indeed, the serum protein signature even reflects the efficiency of anti-PD-1 therapy of CMM patients and can be substantial for therapeutic indications (112).

Similarly to other types of tumours, an elevated serum level of IL6 in CMM has been observed (111), which has reached some prognostic validity (113). Serum elevation of
IL6 sensibly reflected the tumour burden and indicated a relapse of the disease or insensitivity to tumour therapy in several studies (114-116).

A similar finding was observed in the case of serum levels of IL8 $(71,117,118)$. Interestingly, the levels of IL6, IL8, and VEGFA correlated with the level of Breslow index at the time of diagnosis $(117,119)$. Moreover, the amount of VEGFA also depended on the stage of the disease (120). As IL8 also supports CMM neovascularisation, it is not surprising that the elevation of the serum level of both IL8 and VEGFA correlates with the progression of the disease and poor survival of CMM patients (121). Proteins of the TGF- $\beta$ family are also elevated in the sera of CMM patients, and the prognostic relevance of these factors has been proposed (122). Elevated concentration of factors with immunomodulatory activity such as IL6 and/IL10 influence the presence of self-renewal tumour-initiating (stem) cells in CMM (123).

Serum protein imbalance influences premetastatic niche formation. Based on the selected examples, it is possible to demonstrate the systemic effect of CMM. The serum/plasma of CMM patients contains numerous bioactive proteins and exosomes that are transported to the distant parts of the patient's body through the vessels (Fig. 2B-D). These factors participate in the preparation of a premetastatic niche suitable for cancer cell homing and metastasis formation (124). Under the influence of CMM-derived exosomes, the dermal fibroblasts reprogram their metabolism significantly (125). The distant dermal fibroblasts from CMM patients at the stage of metastatic tumour dissemination differ from the normal dermal fibroblasts from healthy donors. The phenotype of distant dermal fibroblasts, as well as the expression profile and methylation profile of gene promoters, is shifted closer to CAFs (126). Due to this activation, it is possible to hypothesise that the tissue microenvironment in the distant body parts is influenced by the released bioactive factors from the melanoma microenvironment. It is, therefore, likely that melanoma becomes a systemic disease very early. If so, it is the signalling in the primary tumour that already prepares the rest of the organism to host CMM cells and facilitate metastases (114) (Fig. 2B).

\section{Intravasation and extravasation of CMM cells and their inhibition via migrastatics}

In recent years, the term 'migrastatics' has been introduced for drugs interfering with all modes of cancer cell invasion (115). Migrastatics inhibit local invasion and consequent metastasis. This group of drugs was recently established to define and distinguish them from conventional cytostatic drugs that traditionally target cell proliferation. Malignant melanoma, therefore, seems to be a tempting disease for validation of this concept.

Endothelial cells of capillaries are also an important structure of the cancer microenvironment. Migrating CMM cells adhere to the capillary endothelium, intercalate between endothelial cells, and migrate throughout the vessels in both directions. From the endothelial cell perspective, this process is not passive. Endothelial cells actively participate in extravasation, where the role of $\mathrm{N}$-cadherin has been broadly 
investigated (117). It seems to be also controlled by CD146, which cooperates with VEGFA. CD146 is also elevated in the patients' serum/plasma (127).

On the other hand, VE-cadherin expressed on the surface of endothelial cells prevents the migration of cancer cells through the endothelium of capillaries. VE-cadherin must, therefore, be eliminated from the site of malignant cell migration (128). P-selectin has an essential role in the recruitment of inflammatory cells to the site of inflammation, so-called homing.

P-selectin expression on endothelial cells is under the control of the local microenvironment. Expression of this molecule on endothelial cells and blood platelets seems to be a prerequisite for successful metastasising of CMM cells to the target tissue $(129,130)$. P-selectin expression on the surface of endothelial cells is induced by STAT3 activation (129). IL6 is available in the serum of CMM patients, and it is known as a potent activator of STAT3. The observation that capsular polysaccharides from E. coli attenuate adhesion of CMM cells to the endothelium via P-selectin demonstrates the specificity of this interaction (130). Endogenous lectin galectin-3 locally accumulates in inflamed tissues, including endothelium. This lectin also enhances invasion of CMM cells, e.g., to the lungs (131). These examples show that an imbalance in serum proteins can participate in the process of extravasation of CMM cells to the target tissue and metastasising.

Therefore, the combination of migrastatics with other groups of traditional oncologic drugs may be possible. Beyond that, we suggest that directed therapy (biologics, small-molecule receptor-associated kinase inhibitors) against the most prominent inflammatory cytokines, namely IL6, could bring highly desirable synergism. However, it seems evident that inhibition of the IL6 signalling axis is not sufficient and must, therefore, be accompanied by simultaneous blockade of other proteins/receptors such as IL8, VEGFA and MFGE8 $(48,132)$. The therapeutic blockade of IL6, in combination with checkpoint inhibitor anti-PD1, represents an interesting possibility of overcoming some immunological mechanisms of resistance. IL6 blockade upregulated expression of PD-L1 on melanoma cells in a mouse model and may sensitise melanoma to this treatment (133). These findings underscore the importance of the IL6-PD1/PD-L1 crosstalk in the tumour microenvironment of melanoma.

The local microenvironment and its control by bioactive factors can be a highly relevant target in the prevention of the deadly complication of malignant disease (Fig. 2D).

\section{Cancer-associated wasting and cachexia as a terminal complication of CMM; clinically relevant complications are also associated with factors of intercellular crosstalk}

Advanced stages of cancer, including CMM, are associated with metastasising, which in the case of CMM has a character of extensive generalisation. The increasing burden of tumour cells generates an imbalance in growth factors, cytokines and chemokines, among which IL6 seems to have the leading position (80). This stage of the disease is usually terminated by cancer-associated cachexia (CAC), which affects approximately 16 patients per 100,000 individuals (134)
(Fig. 2D). CAC is a highly complex and multifaceted catabolic process (135). IL6, in cooperation with TNF $\alpha$ and IL1 $\beta$ influences the metabolism of striated muscle fibres, adipocytes and hepatocytes $(136,137)$. The level of the mentioned factors in the serum can even predict the onset of CAC and survival of cancer patients (138). The terminal stage of cancer is also associated with decreased food intake in cancer patients, which is called anorexia (139). IL6 seems to be linked to the control of food intake, where it inhibits the appetite and participates in the development of anorexia (140). TNF $\alpha$ and IL6 can cross the blood-brain barrier (141). TNF $\alpha$, IL1 and IL6 can interact with hypothalamic neurons and affect the serotoninergic metabolism, which can be reflected by decreased food intake (142). Patients with advanced cancer frequently suffer from depression that seems to be associated with elevation of IL6, IL10 and TNF $\alpha$ (143). On the other hand, the serum levels of IL6 (and also IL8) are significantly elevated in tumour-free patients with bipolar disease, but not with major depressive disorder (144). This section demonstrates that factors produced by the cancer ecosystem have a strong systemic effect by which they influence the metabolic functions of cancer patients, resulting in wasting and death.

\section{Conclusion}

CMM, similarly to the majority of cancers, can be characterised as a genetic abnormality and a regulation failure in which cancer cells employ predestined pathophysiological pathways that are normally activated in the course of organism growth, tissue regeneration and repair. This deregulation is typically associated with accumulation of mutations acquired during the ageing of the individual.

The progression of CMM from tumour initiation to the systemic effect on the patient's metabolism is organised according to a quite uniform scenario (Fig. 2A-D). The intercellular crosstalk within this ecosystem is mediated either directly by intercellular contacts, or indirectly by paracrine secretion of numerous active molecules. This interconnection strengthens the malignant potential of cancer cells, and it can inhibit the anticancer immune response or protect malignant cells from the harmful effect of oncological therapy. A plethora of bioactive factors are transported via vessels and significantly influence even the distant tissue. Collectively, these factors prepare a suitable microenvironment for the malignant cell extravasation and metastasising, the premetastatic niche. The increasing mass of CMM cells in the body of patients generates a cancer-induced profile of inflammatory mediators in the patients' serum. The systemic availability of these bioactive molecules triggers mental disorders, depression, and mental anorexia-associated problems with food intake. Wasting leads to cancer cachexia and death. Based on this scenario, it is evident that besides the conventional anticancer therapy, it would be necessary to influence the migration of CMM cells and their metastasising - the concept of migrastatics (115). Because the CMM microenvironment stimulates malignant cell invasiveness (145), targeting both cancerous and non-cancerous cells of the tumour ecosystem and their products seems to be a promising approach. IL6 and its signalling pathway influence CMM cell growth and migration, but it can also 
positively affect the entire patient metabolism and mental status (82). Therefore, targeting the IL6/IL6R/STAT3 axis as a new therapeutic modality was enthusiastically expected, but, unfortunately, the reality did not meet this expectation (146). The progress in the detection of clinically relevant markers using a robust omics approach that includes stromal factors can be translated into personalised therapy of CMM (147). For example, a combination of blocking the anti-IL6 axis with drugs blocking other signalling pathways seems to be promising for future trials (48). It can be hypothesised that the progress in diagnostics and therapy covering the complex ecosystem of melanoma can bring some benefit to CMM patients.

\section{Acknowledgements}

Authors are grateful to Dr Šárka Takáčová for her assistance in English language editing of this revised version.

\section{Funding}

The project 'Centre for Tumour Ecology-Research of the Cancer Microenvironment Supporting Cancer Growth and Spread' (reg. no. CZ.02.1.01/0.0/0.0/16_019/00007 $85)$ is supported by the Operational Programme 'Research, Development and Education'. Additional support was received from the Ministry of Education, Youth and Sports of CR within the National Sustainability Programme II (Project BIOCEV-FAR, reg. no. LQ1604), project BIOCEV (CZ.1.05/1.1.00/02.0109), grant no. CZ.1.05/2.1.00/19.0400 supported by the Research and Development for Innovations Operational Programme, co-financed by the European Regional Development Fund and the state budget of the Czech Republic, from the Grant Agency of the Czech Republic, project no. 19-05048S and from Charles University project PROGRES Q28.

\section{Availability of data and materials}

All data and information are supported by relevant references.

\section{Authors' contributions}

Conceptualisation, data collection and manuscript preparation were carried out by KSm, OK and LL Manuscript preparation was conducted by JK, JŠ, KSt and BD.

\section{Ethics approval and consent to participate}

Not applicable.

\section{Patient consent for publication}

The images in Fig. 1 were kindly provided by the Department of Dermatovenereology, First Faculty of Medicine, Charles University with explicit informed consent.

\section{Competing interests}

The authors declare no competing interests.

\section{References}

1. Sacchetto L, Zanetti R, Comber H, Bouchardy C, Brewster DH, Broganelli P, Chirlaque MD, Coza D, Galceran J, Gavin A, et al: Trends in incidence of thick, thin and in situ melanoma in Europe. Eur J Cancer 92: 108-118, 2018.

2. Rabbie R, Ferguson P, Molina-Aguilar C, Adams DJ and Robles-Espinoza CD: Melanoma subtypes: Genomic profiles, prognostic molecular markers and therapeutic possibilities. J Pathol 247: 539-551, 2019.

3. Lorentzen HF: Targeted therapy for malignant melanoma. Curr Opin Pharmacol 46: 116-121, 2019.

4. Paget S: The distribution of secondary growths in cancer of the breast. Lancet 133: 571-573, 1889.

5. Faries MB, Thompson JF, Cochran AJ, Andtbacka RH, Mozzillo N, Zager JS, Jahkola T, Bowles TL, Testori A, Beitsch PD, et al: Completion dissection or observation for sentinel-node metastasis in melanoma. N Engl J Med 376: 2211-2222, 2017.

6. Nathanson SD: Insights into the mechanisms of lymph node metastasis. Cancer 98: 413-423, 2003.

7. Barth A, Wanek LA and Morton DL: Prognostic factors in 1,521 melanoma patients with distant metastases. J Am Coll Surg 181: 193-201, 1995.

8. Damsky WE Jr and Bosenberg M: Mouse melanoma models and cell lines. Pigment Cell Melanoma Res 23: 853-859, 2010.

9. Abdel-Ghany M, Cheng HC, Elble RC and Pauli BU: The breast cancer $\beta 4$ integrin and endothelial human CLCA2 mediate lung metastasis. J Biol Chem 276: 25438-25446, 2001.

10. Tawbi HA, Boutros C, Kok D, Robert C and McArthur G: New era in the management of melanoma brain metastases. Am Soc Clin Oncol Educ Book 38: 741-750, 2018.

11. Menter DG, Herrmann JL and Nicolson GL: The role of trophic factors and autocrine/paracrine growth factors in brain metastasis. Clin Exp Metastasis 13: 67-88, 1995.

12. Balch CM, Houghton AN, Sober AJ and Soong S: Cutaneous Melanoma, 4th Edition. Dermatologic Surg 31: 1715-1715, 2005.

13. Murakami T, Cardones AR and Hwang ST: Chemokine receptors and melanoma metastasis. J Dermatol Sci 36: 71-78, 2004.

14. Martinez-Rodriguez M, Thompson AK and Monteagudo C: High CCL27 immunoreactivity in 'supratumoral' epidermis correlates with better prognosis in patients with cutaneous malignant melanoma. J Clin Pathol 70: 15-19, 2017.

15. Ben-Baruch A: Organ selectivity in metastasis: Regulation by chemokines and their receptors. Clin Exp Metastasis 25: 345-356, 2008.

16. Marcoval J, Ferreres JR, Martín C, Gómez S, Penín RM, Ochoa de Olza M and Fabra À: Patterns of Visceral Metastasis in Cutaneous Melanoma: A Descriptive Study. Actas Dermosifiliog 104: 593-597, 2013.

17. Adler NR, Wolfe R, Kelly JW, Haydon A, McArthur GA, McLean CA and Mar VJ: Tumour mutation status and sites of metastasis in patients with cutaneous melanoma. Br J Cancer 117: 1026-1035, 2017.

18. Holt JB, Sangueza OP, Levine EA, Shen P, Bergman S, Geisinger KR and Creager AJ: Nodal melanocytic nevi in sentinel lymph nodes. Correlation with melanoma-associated cutaneous nevi. Am J Clin Pathol 121: 58-63, 2004.

19. Ji Y, Hao H, Reynolds K, McMahon M and Zhou CJ: Wnt signaling in neural crest ontogenesis and oncogenesis. Cells 8: $1173,2019$.

20. Lim J, Thiery JP, Kassem Y, Kalcheim C, Moens CB, Burden SJ and Granato M: Epithelial-mesenchymal transitions: Insights from development. Development 139: 3471-3486, 2012.

21. Mayor R and Theveneau E: The neural crest. Development 140: 2247-2251, 2013.

22. Hall BK: The neural crest and neural crest cells: Discovery and significance for theories of embryonic organization. J Biosci 33: 781-793, 2008.

23. Mort RL, Jackson IJ and Patton EE: The melanocyte lineage in development and disease. Development 142: 620-632, 2015.

24. Duband JL, Monier F, Delannet M and Newgreen D: Epithelium-mesenchyme transition during neural crest development. Acta Anat (Basel) 154: 63-78, 1995.

25. Vega-Lopez GA, Cerrizuela S and Aybar MJ: Trunk neural crest cells: Formation, migration and beyond. Int J Dev Biol 61: 5-15, 2017.

26. Larribère L and Utikal J: Stem cell-derived models of neural crest are essential to understand melanoma progression and therapy resistance. Front Mol Neurosci 12: 111, 2019. 
27. Gallik KL, Treffy RW, Nacke LM, Ahsan K, Rocha M, Green-Saxena A and Saxena A: Neural crest and cancer: Divergent travelers on similar paths. Mech Dev 148: 89-99, 2017.

28. Sieber-Blum M and Grim M: The adult hair follicle: Cradle for pluripotent neural crest stem cells. Birth Defects Res C Embryo Today 72: 162-172, 2004

29. Person F, Wilczak W,Hube-Magg C, Burdelski C, Möller-Koop C, SimonR,NoriegaM,SauterG,SteurerS,Burdak-RothkammS,etal: Prevalence of $\beta$ III-tubulin (TUBB3) expression in human norma tissues and cancers. Tumour Biol 39: 1010428317712166, 2017.

30. Stasiak M,Boncela J,Perreau C,Karamanou K, Chatron-Colliet A, Proult I, Przygodzka P, Chakravarti S, Maquart FX, Kowalska MA, et al: Lumican inhibits SNAIL-induced melanoma cell migration specifically by blocking MMP-14 activity. PLoS One 11: e0150226, 2016.

31. Yang X, Liang R, Liu C, Liu JA, Cheung MPL, Liu X, Man OY, Guan XY, Lung HL and Cheung M: SOX9 is a dose-dependent metastatic fate determinant in melanoma. J Exp Clin Cancer Res 38: 17, 2019.

32. Lee H, Torres FX, McLean SA, Chen R and Lee MW: Immunophenotypic heterogeneity of primary sinonasal melanoma with aberrant expression of neuroendocrine markers and calponin. Appl Immunohistochem Mol Morphol 19: 48-53, 2011.

33. Tudrej KB, Czepielewska E and Kozłowska-Wojciechowska M: SOX10-MITF pathway activity in melanoma cells. Arch Med Sci 13: 1493-1503, 2017

34. Iwakami Y, Yokoyama S, Watanabe $\mathrm{K}$ and Hayakawa $\mathrm{Y}$ : STAM-binding protein regulates melanoma metastasis through SLUG stabilization. Biochem Biophys Res Commun 507 484-488, 2018.

35. Goding CR and Arnheiter H: MITF-the first 25 years. Genes Dev 33: 983-1007, 2019.

36. Campbell K, Kumarapeli AR, Gokden N, Cox RM, Hutchins L and Gardner JM: Metastatic melanoma with dedifferentiation and extensive rhabdomyosarcomatous heterologous component. J Cutan Pathol 45: 360-364, 2018.

37. Krejčí E and Grim M: Isolation and characterization of neural crest stem cells from adult human hair follicles. Folia Biol (Praha) 56: 149-157, 2010

38. Marzagalli M, Raimondi M, Fontana F, Montagnani Marelli M, Moretti RM and Limonta P: Cellular and molecular biology of cancer stem cells in melanoma: Possible therapeutic implications. Semin Cancer Biol 59: 221-235, 2019.

39. Kasemeier-Kulesa JC, Teddy JM, Postovit LM, Seftor EA, Seftor REB, Hendrix MJC and Kulesa PM: Reprogramming multipotent tumor cells with the embryonic neural crest microenvironment. Dev Dyn 237: 2657-2666, 2008.

40. Kaufman CK, Mosimann C, Fan ZP, Yang S, Thomas AJ, Ablain J, Tan JL, Fogley RD, van Rooijen E, Hagedorn EJ, et al: A zebrafish melanoma model reveals emergence of neural crest identity during melanoma initiation. Science 351: aad2197, 2016

41. Agnoletto C, Corrà F, Minotti L, Baldassari F, Crudele F, Cook WJJ, Di Leva G, d'Adamo AP, Gasparini P and Volinia S: Heterogeneity in circulating tumor cells: The relevance of the stem-cell subset. Cancers (Basel) 11: 11, 2019.

42. Gkountela S and Aceto N: Stem-like features of cancer cells on their way to metastasis. Biol Direct 11: 33, 2016

43. Empringham B, Chiang KY and Krueger J: Collection of hematopoietic stem cells and immune effector cells in small children. Transfus Apheresis Sci 57: 614-618, 2018.

44. Feehan J, Nurgali K, Apostolopoulos V, Al Saedi A and Duque G: Circulating osteogenic precursor cells: Building bone from blood. EBioMedicine 39: 603-611, 2019.

45. Ratajczak MZ, Bujko K, Mack A, Kucia M and Ratajczak J: Cancer from the perspective of stem cells and misappropriated tissue regeneration mechanisms. Leukemia 32: 2519-2526, 2018

46. Lacina L, Plzak J, Kodet O, Szabo P, Chovanec M, Dvorankova B and Smetana K Jr: Cancer microenvironment: What can we learn from the stem cell niche. Int J Mol Sci 16: 24094-24110, 2015.

47. Hill BS, Pelagalli A, Passaro N and Zannetti A: Tumor-educated mesenchymal stem cells promote pro-metastatic phenotype. Oncotarget 8: 73296-73311, 2017.

48. Plzák J, Bouček J, Bandúrová V, Kolář M, Hradilová M, Szabo P, Lacina L, Chovanec M and Smetana K Jr: The head and neck squamous cell carcinoma microenvironment as a potential target for cancer therapy. Cancers (Basel) 11: 11, 2019.

49. Lacina L, Kodet O, Dvořánková B, Szabo P and Smetana K Jr: Ecology of melanoma cell. Histol Histopathol 33: 247-254, 2018.
50. Preisner F, Leimer U, Sandmann S, Zoernig I, Germann G and Koellensperger E: Impact of human adipose tissue-derived stem cells on malignant melanoma cells in an in vitro co-culture model. Stem Cell Rev Rep 14: 125-140, 2018.

51. Dvořánková B, Smetana K Jr, Ríhová B, Kučera J, Mateu R and Szabo P: Cancer-associated fibroblasts are not formed from cancer cells by epithelial-to-mesenchymal transition in $\mathrm{nu} / \mathrm{nu}$ mice. Histochem Cell Biol 143: 463-469, 2015.

52. Inada M, Takita M, Yokoyama S, Watanabe K, Tominari $T$, Matsumoto C, Hirata M, Maru Y, Maruyama T, Sugimoto Y, et al: Direct melanoma cell contact induces stromal cell autocrine prostaglandin E2-EP4 receptor signaling that drives tumor growth, angiogenesis, and metastasis. J Biol Chem 290: 29781-29793, 2015.

53. Ziani L, Safta-Saadoun TB, Gourbeix J, Cavalcanti A, Robert C, Favre G, Chouaib S and Thiery J: Melanoma-associated fibroblasts decrease tumor cell susceptibility to NK cell-mediated killing through matrix-metalloproteinases secretion. Oncotarget 8: 19780-19794, 2017.

54. Kodet O, Lacina L, Krejčí E, Dvořánková B, Grim M, Štork J, Kodetová D, Vlček C, Sáchová J, Kolář M, et al: Melanoma cells influence the differentiation pattern of human epidermal keratinocytes. Mol Cancer 14: 1, 2015.

55. Van Kilsdonk JWJ, Bergers M, Van Kempen LCLT, Schalkwijk J and Swart GWM: Keratinocytes drive melanoma invasion in a reconstructed skin model. Melanoma Res 20: 372-380, 2010.

56. Ciołczyk-Wierzbicka D and Laidler P: The inhibition of invasion of human melanoma cells through $\mathrm{N}$-cadherin knock-down. Med Oncol 35: 42, 2018.

57. Chung H, Jung H, Jho EH, Multhaupt HAB, Couchman JR and Oh ES: Keratinocytes negatively regulate the $\mathrm{N}$-cadherin levels of melanoma cells via contact-mediated calcium regulation. Biochem Biophys Res Commun 503: 615-620, 2018.

58. Nikkola J, Vihinen P, Vlaykova T, Hahka-Kemppinen M, Heino J and Pyrhönen S: Integrin chains $\beta 1$ and alphav as prognostic factors in human metastatic melanoma. Melanoma Res 14: 29-37, 2004.

59. Van Belle PA, Elenitsas R, Satyamoorthy K, Wolfe JT, Guerry D IV, Schuchter L, Van Belle TJ, Albelda S, Tahin P, Herlyn M, et al: Progression-related expression of $\beta 3$ integrin in melanomas and nevi. Hum Pathol 30: 562-567, 1999.

60. Li G, Satyamoorthy K, Meier F, Berking C, Bogenrieder T and Herlyn M: Function and regulation of melanoma-stromal fibroblast interactions: When seeds meet soil. Oncogene 22: 3162-3171, 2003.

61. Brandner JM and Haass NK: Melanoma's connections to the tumour microenvironment. Pathology 45: 443-452, 2013.

62. Peitsch WK, Doerflinger Y, Fischer-Colbrie R, Huck V, Bauer AT, Utikal J, Goerdt S and Schneider SW: Desmoglein 2 depletion leads to increased migration and upregulation of the chemoattractant secretoneurin in melanoma cells. PLoS One 9: e89491, 2014.

63. Tan LY, Mintoff C, Johan MZ, Ebert BW, Fedele C, Zhang YF, Szeto P, Sheppard KE, McArthur GA, Foster-Smith E, et al: Desmoglein 2 promotes vasculogenic mimicry in melanoma and is associated with poor clinical outcome. Oncotarget 7: 46492-46508, 2016

64. Klemke M, Weschenfelder T, Konstandin MH and Samstag Y: High affinity interaction of integrin $\alpha 4 \beta 1$ (VLA-4) and vascular cell adhesion molecule 1 (VCAM-1) enhances migration of human melanoma cells across activated endothelial cell layers. J Cell Physiol 212: 368-374, 2007.

65. Lacaria L, Lange JR, Goldmann WH, Rico F and Alonso JL: av $\beta 3$ integrin expression increases elasticity in human melanoma cells. Biochem Biophys Res Commun 525: 836-840, 2020.

66. Bedogni B: Notch signaling in melanoma: Interacting pathways and stromal influences that enhance Notch targeting. Pigment Cell Melanoma Res 27: 162-168, 2014.

67. Jobe NP, Rösel D, Dvořánková B, Kodet O, Lacina L, Mateu R, Smetana K and Brábek J: Simultaneous blocking of IL-6 and IL-8 is sufficient to fully inhibit CAF-induced human melanoma cell invasiveness. Histochem Cell Biol 146: 205-217, 2016.

68. Jobe NP, Živicová V, Mifková A, Rösel D, Dvořánková B, Kodet O, Strnad H, Kolář M, Šedo A, Smetana K Jr, et al: Fibroblasts potentiate melanoma cells in vitro invasiveness induced by UV-irradiated keratinocytes. Histochem Cell Biol 149: 503-516, 2018.

69. Strnadova K, Sandera V, Dvorankova B, Kodet O, Duskova M, Smetana K and Lacina L: Skin aging: The dermal perspective. Clin Dermatol 37: 326-335, 2019. 
70.Payne AS and Cornelius LA: The role of chemokines in melanoma tumor growth and metastasis. J Invest Dermatol 118: 915-922, 2002.

71. Gebhardt C, Averbeck M, Viertel A, Kauer F, Saalbach A, Anderegg U and Simon JC: Ultraviolet-B irradiation enhances melanoma cell motility via induction of autocrine interleukin 8 secretion. Exp Dermatol 16: 636-643, 2007.

72. Araki K, Shimura T, Yajima T, Tsutsumi S, Suzuki H, Okada K, Kobayashi T, Raz A and Kuwano H: Phosphoglucose isomerase/autocrine motility factor promotes melanoma cell migration through ERK activation dependent on autocrine production of interleukin-8. J Biol Chem 284: 32305-32311, 2009.

73.Kemp DM, Pidich A, Larijani M, Jonas R, Lash E, Sato T, Terai M, De Pizzol M, Allegretti M, Igoucheva O, et al: Ladarixin, a dual CXCR1/2 inhibitor, attenuates experimental melanomas harboring different molecular defects by affecting malignant cells and tumor microenvironment. Oncotarget 8 14428-14442, 2017

74. Brennecke S, Deichmann M, Naeher H and Kurzen H: Decline in angiogenic factors, such as interleukin-8, indicates response to chemotherapy of metastatic melanoma. Melanoma Res 15: 515-522, 2005.

75. Gabellini C, Trisciuoglio D, Desideri M, Candiloro A, Ragazzoni Y, Orlandi A, Zupi G and Del Bufalo D: Functional activity of CXCL8 receptors, CXCR1 and CXCR2, on human malignant melanoma progression. Eur J Cancer 45: 2618-2627, 2009 .

76. Nürnberg W, Tobias D, Otto F, Henz BM and Schadendorf D: Expression of interleukin-8 detected by in situ hybridization correlates with worse prognosis in primary cutaneous melanoma. J Pathol 189: 546-551, 1999.

77. Ortega-Bernal D, La Rosa CHG, Arechaga-Ocampo E, Alvarez-Avitia MA, Moreno NS and Rangel-Escareño C: A meta-analysis of transcriptome datasets characterizes malignant transformation from melanocytes and nevi to melanoma. Oncol Lett 16: 1899-1911, 2018

78. Adamski V, Mentlein R, Lucius R, Synowitz M, Held-Feindt J and Hattermann $\mathrm{K}$ : The chemokine receptor CXCR6 evokes reverse signaling via the transmembrane chemokine CXCL16. Int J Mol Sci 18: 18, 2017.

79. da Silva WC, Oshiro TM, de Sá DC, Franco DDGS, Festa Neto C and Pontillo A: Genotyping and differential expression analysis of inflammasome genes in sporadic malignant melanoma reveal novel contribution of CARD8, IL1B and IL18 in melanoma susceptibility and progression. Cancer Genet 209: 474-480, 2016.

80.Lacina L, Brábek J, Král V, Kodet O and Smetana K Jr: Interleukin-6: A molecule with complex biological impact in cancer. Histol Histopathol 34: 125-136, 2019.

81. Armstrong CA, Murray N, Kennedy M, Koppula SV, Tara D and Ansel JC: Melanoma-derived interleukin 6 inhibits in vivo melanoma growth. J Invest Dermatol 102: 278-284, 1994.

82. Lu C and Kerbel RS: Interleukin-6 undergoes transition from paracrine growth inhibitor to autocrine stimulator during human melanoma progression. J Cell Biol 120: 1281-1288, 1993.

83. Elias EG, Hasskamp JH and Sharma BK: Cytokines and growth factors expressed by human cutaneous melanoma. Cancers (Basel) 2: 794-808, 2010.

84.Linnskog R, Jönsson G, Axelsson L, Prasad CP and Andersson T: Interleukin- 6 drives melanoma cell motility through p38 $\alpha$-MAPK-dependent up-regulation of WNT5A expression. Mol Oncol 8: 1365-1378, 2014.

85. Karst AM, Gao K, Nelson CC and Li G: Nuclear factor kappa B subunit p50 promotes melanoma angiogenesis by upregulating interleukin-6 expression. Int J Cancer 124: 494-501, 2009.

86. Nagai H, Oniki S, Fujiwara S, Xu M, Mizoguchi I, Yoshimoto T and Nishigori C: Antitumor activities of interleukin-27 on melanoma. Endocr Metab Immune Disord Drug Targets 10: 41-46, 2010

87. Shinozaki Y, Wang S, Miyazaki Y, Miyazaki K, Yamada H, Yoshikai Y, Hara $\mathrm{H}$ and Yoshida $\mathrm{H}$ : Tumor-specific cytotoxic $\mathrm{T}$ cell generation and dendritic cell function are differentially regulated by interleukin 27 during development of anti-tumor immunity. Int J Cancer 124: 1372-1378, 2009.

88. Chiba Y, Mizoguchi I, Mitobe K, Higuchi K, Nagai H, Nishigori C, Mizuguchi J and Yoshimoto T: IL-27 enhances the expression of TRAIL and TLR3 in human melanomas and inhibits their tumor growth in cooperation with a TLR3 agonist poly(I:C) partly in a TRAIL-dependent manner. PLoS One 8 e76159, 2013.
89. Bisevac JP, Stanojevic I, Mijuskovic Z, Banovic T, Djukic M and Vojvodic D: High interleukin 27 production is associated with early clinical stage and localized disease in patients with melanoma. J Med Biochem 35: 443-450, 2016

90. Onoue K, Kusubashi H, Sato Y, Wakitani S and Takagi M Quantitative correlation between production rate of melanoma inhibitory activity and aggrecan gene expression level during differentiation from mesenchymal stem cells to chondrocytes and redifferentiation of chondrocytes. J Biosci Bioeng 111: 594-596, 2011.

91. Decarlo K, Yang S, Emley A, Wajapeyee N, Green M and Mahalingam M: Oncogenic BRAF-positive dysplastic nevi and the tumor suppressor IGFBP7 - challenging the concept of dysplastic nevi as precursor lesions? Hum Pathol 41: 886-894, 2010.

92. Yotsumoto F, Yagi H, Suzuki SO, Oki E, Tsujioka H, Hachisuga T, Sonoda K, Kawarabayashi T,Mekada E and Miyamoto S: Validation of HB-EGF and amphiregulin as targets for human cancer therapy. Biochem Biophys Res Commun 365: 555-561, 2008.

93. Marchetti D and Nicolson GL: Neurotrophin stimulation of human melanoma cell invasion: Selected enhancement of heparanase activity and heparanase degradation of specific heparan sulfate subpopulations. Adv Enzyme Regul 37: 111-134, 1997.

94. Antunes LCM, Cartell A, de Farias CB, Bakos RM, Roesler R and Schwartsmann G: Tropomyosin-related kinase receptor and neurotrophin expression in cutaneous melanoma is associated with a poor prognosis and decreased survival. Oncology 97: 26-37, 2019

95. Li JR, Wang JQ, Gong Q, Fang RH and Guo YL: MicroRNA-328 inhibits proliferation of human melanoma cells by targeting TGF32. Asian Pac J Cancer Prev 16: 1575-1579, 2015

96. Hutchenreuther J, Vincent K, Norley C, Racanelli M, Gruber SB JohnsonTM,Fullen DR, Raskin L,Perbal B, HoldsworthDW, etal: Activation of cancer-associated fibroblasts is required for tumor neovascularization in a murine model of melanoma. Matrix Biol 74: 52-61, 2018.

97. Straussman R, Morikawa T, Shee K, Barzily-Rokni M, Qian ZR, Du J, Davis A, Mongare MM, Gould J, Frederick DT, et al: Tumour micro-environment elicits innate resistance to RAF inhibitors through HGF secretion. Nature 487: 500-504, 2012.

98. Capparelli C, Rosenbaum S, Berger AC and Aplin AE Fibroblast-derived neuregulin 1 promotes compensatory ErbB3 receptor signaling in mutant BRAF melanoma. J Biol Chem 290 24267-24277, 2015

99. Ruivo CF, Adem B, Silva M and Melo SA: The biology of cancer exosomes: Insights and new perspectives. Cancer Res 77 6480-6488, 2017

100. Hood JL: Melanoma exosome induction of endothelial cell GM-CSF in pre-metastatic lymph nodes may result in different M1 and M2 macrophage mediated angiogenic processes. Med Hypotheses 94: 118-122, 2016.

101. Xiao D, Barry S, Kmetz D, Egger M, Pan J, Rai SN, Qu J, McMasters KM and Hao $\mathrm{H}$ : Melanoma cell-derived exosomes promote epithelial-mesenchymal transition in primary melanocytes through paracrine/autocrine signaling in the tumor microenvironment. Cancer Lett 376: 318-327, 2016.

102. Gowda R, Robertson BM, Iyer S, Barry J, Dinavahi SS and Robertson GP: The role of exosomes in metastasis and progression of melanoma. Cancer Treat Rev 85: 101975, 2020.

103. Gajos-Michniewicz A and Czyz M: Role of mirnas in melanoma metastasis. Cancers (Basel) 11: 11, 2019.

104. Clayton A, Mitchell JP, Court J, Mason MD and Tabi Z: Human tumor-derived exosomes selectively impair lymphocyte responses to interleukin-2. Cancer Res 67: 7458-7466, 2007.

105. Gerloff D, Lützkendorf J, Moritz RKC, Wersig T, Mäder K, Müller LP and Sunderkötter C: Melanoma-derived exosomal mir-125b-5p educates tumor associated macrophages (TAMs) by targeting lysosomal acid lipase A (LIPA). Cancers (Basel) 12: 12, 2020.

106. Bardi GT, Smith MA and Hood JL: Melanoma exosomes promote mixed M1 and M2 macrophage polarization. Cytokine 105: 63-72, 2018

107. Gershenwald JE and Scolyer RA: Melanoma Staging: American Joint Committee on Cancer (AJCC) 8th Edition and Beyond. Ann Surg Oncol 25: 2105-2110, 2018.

108. Michielin O, van Akkooi ACJ, Ascierto PA, Dummer R and Keilholz U; ESMO Guidelines Committee. Electronic address: clinicalguidelines@esmo.org: Cutaneous melanoma: ESMO Clinical Practice Guidelines for diagnosis, treatment and follow-up. Ann Oncol 30: 1884-1901, 2019.

109. Riechers A and Bosserhoff AK: Melanoma inhibitory activity in melanoma diagnostics and therapy - a small protein is looming large. Exp Dermatol 23: 12-14, 2014. 
110. Forgber M, Trefzer U, Sterry W and Walden P: Proteome serological determination of tumor-associated antigens in melanoma. PLoS One 4: e5199, 2009.

111. Muqaku B, Eisinger M, Meier SM, Tahir A, Pukrop T, Haferkamp S, Slany A, Reichle A and Gerner C: Multi-omics analysis of serum samples demonstrates reprogramming of organ functions via systemic calcium mobilization and platelet activation in metastatic melanoma. Mol Cell Proteomics 16 86-99, 2017.

112. WeberJS,SznolM,SullivanRJ,BlackmonS,BolandG,KlugerHM, Halaban R, Bacchiocchi A, Ascierto PA, Capone M, et al: A serum protein signature associated with outcome after anti-PD-1 therapy in metastatic melanoma. Cancer Immuno Res 6: 79-86, 2018.

113. Hoejberg L, Bastholt L, Johansen JS, Christensen IJ, Gehl J and Schmidt H: Serum interleukin-6 as a prognostic biomarker in patients with metastatic melanoma. Melanoma Res 22: 287-293, 2012.

114. Correa D, Somoza RA, Lin P, Schiemann WP and Caplan AI: Mesenchymal stem cells regulate melanoma cancer cells extravasation to bone and liver at their perivascular niche. Int J Cancer 138: 417-427, 2016.

115. Gandalovičová A, Rosel D, Fernandes M, Veselý P, Heneberg P, Cermák V, Petruželka L, Kumar S, Sanz-Moreno V and Brábek J: Migrastatics-anti-metastatic and anti-invasion Drugs: Promises and challenges. Trends Cancer 3: 391-406, 2017.

116. Herman H, Fazakas C, Haskó J, Molnár K, Mészáros Á, Nyúl-Tóth Á,Szabó G, Erdélyi F, Ardelean A,Hermenean A, et al: Paracellular and transcellular migration of metastatic cells through the cerebral endothelium. J Cell Mol Med 23: 2619-2631, 2019

117. Kucera R, Topolcan O, Treskova I, Kinkorova J, Windrichova J, Fuchsova R, Svobodova S, Treska V, Babuska V, Novak J, et al: Evaluation of IL-2, IL-6, IL-8 and IL-10 in malignant melanoma diagnostics. Anticancer Res 35: 3537-3541, 2015.

118. Sanmamed MF, Carranza-Rua O, Alfaro C, Oñate C, Martín-Algarra S, Perez G, Landazuri SF, Gonzalez A, Gross S, Rodriguez I, et al: Serum interleukin-8 reflects tumor burden and treatment response across malignancies of multiple tissue origins. Clin Cancer Res 20: 5697-5707, 2014.

119. Kučera J, Strnadová K, Dvořánková B, Lacina L, Krajsová I, Štork J, Kováŕová H, Skalníková HK, Vodička P, Motlík J, et al Serum proteomic analysis of melanoma patients with immunohistochemical profiling of primary melanomas and cultured cells: Pilot study. Oncol Rep 42: 1793-1804, 2019

120. Pelletier F, Bermont L, Puzenat E, Blanc D, Cairey-Remonnay S, Mougin C, Laurent R, Humbert P and Aubin F: Circulating vascular endothelial growth factor in cutaneous malignant melanoma. Br J Dermatol 152: 685-689, 2005.

121. Ugurel S, Rappl G, Tilgen W and Reinhold U: Increased serum concentration of angiogenic factors in malignant melanoma patients correlates with tumor progression and survival. J Clin Oncol 19: 577-583, 2001.

122. Krasagakis K, Thölke D, Farthmann B, Eberle J, Mansmann U and Orfanos CE: Elevated plasma levels of transforming growth factor (TGF)- $\beta 1$ and TGF- $\beta 2$ in patients with disseminated malignant melanoma. Br J Cancer 77: 1492-1494, 1998.

123. Tuccitto A, Tazzari M, Beretta V, Rini F, Miranda C, Greco A, Santinami M, Patuzzo R, Vergani B, Villa A, et al: Immunomodulatory factors control the fate of melanoma tumor initiating cells. Stem Cells 34: 2449-2460, 2016.

124. Tung KH, Ernstoff MS, Allen C and Shu S: A Review of exosomes and their role in the tumor microenvironment and host-tumor 'macroenvironment'. J Immunol Sci 3: 4-8, 2019.

125. Shu S, Yang Y, Allen CL, Maguire O, Minderman H, Sen A, Ciesielski MJ, Collins KA, Bush PJ, Singh P, et al: Metabolic reprogramming of stromal fibroblasts by melanoma exosome microRNA favours a pre-metastatic microenvironment. Sci Rep 8: 12905, 2018

126. Kodet O, Dvořánková $\mathrm{B}$, Bendlová $\mathrm{B}$, Sýkorová $\mathrm{V}$, Krajsová $\mathrm{I}$, Štork J, Kučera J, Szabo P, Strnad H, Kolář M, et al: Microenvironment driven resistance to B Raf inhibition in a melanoma patient is accompanied by broad changes of gene methylation and expression in distal fibroblasts. Int $\mathrm{J}$ Mol Med 41: 2687-2703, 2018

127. Jouve N, Bachelier R, Despoix N, Blin MG, Matinzadeh MK, Poitevin S, Aurrand-Lions M, Fallague K, Bardin N, Blot-Chabaud M, et al: CD146 mediates VEGF-induced melanoma cell extravasation through FAK activation. Int $\mathrm{J}$ Cancer 137: 50-60,2015.
128. Hamilla SM, Stroka KM and Aranda-Espinoza H: VE-cadherin-independent cancer cell incorporation into the vascular endothelium precedes transmigration. PLoS One 9 e109748, 2014

129. Kim KJ, Kwon SH, Yun JH, Jeong HS, Kim HR, Lee EH, Ye SK and Cho CH: STAT3 activation in endothelial cells is importan for tumor metastasis via increased cell adhesion molecule expression. Oncogene 36: 5445-5459, 2017.

130. Borgenström M, Wärri A, Hiilesvuo K, Käkönen R, Käkönen S, Nissinen L, Pihlavisto M, Marjamäki A, Vlodavsky I, Naggi A, et al O-sulfated bacterial polysaccharides with low anticoagulant activity inhibit metastasis. Semin Thromb Hemost 33: 547-556, 2007.

131. Dange MC, Srinivasan N, More SK, Bane SM, Upadhya A, Ingle $\mathrm{AD}$, Gude RP, Mukhopadhyaya R and Kalraiya RD: Galectin-3 expressed on different lung compartments promotes organ specific metastasis by facilitating arrest, extravasation and organ colonization via high affinity ligands on melanoma cells Clin Exp Metastasis 31: 661-673, 2014

132. Desch A, Strozyk EA, Bauer AT, Huck V, Niemeyer V, Wieland T and Schneider SW: Highly invasive melanoma cells activate the vascular endothelium via an MMP-2/integrin $\alpha v \beta 5$-induced secretion of VEGF-A. Am J Pathol 181: 693-705, 2012.

133. Tsukamoto H, Fujieda K, Miyashita A, Fukushima S, Ikeda T, Kubo Y, Senju S, Ihn H, Nishimura Y and Oshiumi H: Combined blockade of IL6 and PD-1/PD-L1 signaling abrogates mutual regulation of their immunosuppressive effects in the tumor microenvironment. Cancer Res 78: 5011-5022, 2018.

134. Anker MS, Holcomb R, Muscaritoli M, von Haehling S, Haverkamp W, Jatoi A, Morley JE, Strasser F, Landmesser U, Coats AJS, et al: Orphan disease status of cancer cachexia in the USA and in the European Union: A systematic review. J Cachexia Sarcopenia Muscle 10: 22-34, 2019.

135. Loumaye A and Thissen JP: Biomarkers of cancer cachexia. Clin Biochem 50: 1281-1288, 2017.

136. Weidle UH, Klostermann S, Eggle D and Krüger A: Interleukin 6/interleukin 6 receptor interaction and its role as a therapeutic target for treatment of cachexia and cancer. Cancer Genomics Proteomics 7: 287-302, 2010.

137.Zimmers TA, Fishel ML and Bonetto A: STAT3 in the systemic inflammation of cancer cachexia. Semin Cell Dev Biol 54 28-41, 2016

138. Cehreli R, Yavuzsen T, Ates H, Akman T, Ellidokuz H and Oztop I: Can inflammatory and nutritional serum markers predict chemotherapy outcomes and survival in advanced stage nonsmall cell lung cancer patients? BioMed Res Int 2019: $1648072,2019$.

139. Johannes CM and Musser ML: Anorexia and the cancer patient. Vet Clin North Am Small Anim Pract 49: 837-854, 2019.

140. Pisetsky DS, Trace SE, Brownley KA, Hamer RM, Zucker NL, Roux-Lombard P, Dayer JM and Bulik CM: The expression of cytokines and chemokines in the blood of patients with severe weight loss from anorexia nervosa: An exploratory study. Cytokine 69: 110-115, 2014.

141. Rochfort KD and Cummins PM: The blood-brain barrier endothelium: A target for pro-inflammatory cytokines. Biochem Soc Trans 43: 702-706, 2015

142. Dwarkasing JT, Witkamp RF, Boekschoten MV, Ter Laak MC, Heins MS and van Norren K: Increased hypothalamic serotonin turnover in inflammation-induced anorexia. BMC Neurosci 17: 26, 2016.

143. Liu WJ, Wang XD, Wu W and Huang X: Relationship between depression and blood cytokine levels in lung cancer patients. Med Sci (Paris) 34 Focus issue F1: 113-115, 2018

144. Lu YR, Rao YB, Mou YJ, Chen Y, Lou HF, Zhang Y, Zhang DX, Xie HY, Hu LW and Fang P: High concentrations of serum interleukin- 6 and interleukin- 8 in patients with bipolar disorder. Medicine (Baltimore) 98: e14419, 2019.

145. Ju RJ, Stehbens SJ and Haass NK: The role of melanoma cell-stroma interaction in cell motility, invasion, and metastasis. Front Med (Lausanne) 5: 307, 2018.

146. Johnson DE, O'Keefe RA and Grandis JR: Targeting the IL-6/JAK/STAT3 signalling axis in cancer. Nat Rev Clin Oncol 15: 234-248, 2018

147. Donnelly D III, Aung PP and Jour G: The '-OMICS' facet of melanoma: Heterogeneity of genomic, proteomic and metabolomic biomarkers. Semin Cancer Biol 59: 165-174, 2019.

This work is licensed under a Creative Commons Attribution-NonCommercial-NoDerivatives 4.0 International (CC BY-NC-ND 4.0) License. 